\title{
Prolonged apoptosis in mitochondria-rich cells of tilapia (Oreochromis mossambicus) exposed to elevated salinity
}

\author{
Brittany D. Kammerer · Dietmar Kültz
}

Received: 14 October 2008 / Revised: 14 December 2008 / Accepted: 17 December 2008 / Published online: 11 January 2009

(C) The Author(s) 2009. This article is published with open access at Springerlink.com

\begin{abstract}
The time-course of programmed cell death (apoptosis) during reorganization of gill epithelium in salinity-stressed tilapia was analyzed using a recently developed method based on laser scanning cytometry (LSC) of dissociated gill cells. Apoptosis in mitochondriarich cells (MRC) was distinguished from that in other cell types using $\mathrm{Na}^{+} / \mathrm{K}^{+}$ATPase (NKA) as a cell-specific marker. Caspase 3/7 activity in MRC, assessed using LSC and microplate assays, increased significantly starting at $6 \mathrm{~h}$ of salinity stress and remained elevated for at least 5 days. This time-course of apoptosis in MRC during acute salinity stress was reflected in elevated apoptotic DNA fragmentation. In parallel to induction of apoptosis, MRC showed a pronounced shift to G2 phase of the cell cycle, which is indicative of G2/M cell cycle arrest, and an increase in NKA abundance per MRC. Unlike in MRC, apoptosis was not significantly increased in other gill cell types, although there was a small transient increase in DNA fragmentation at $6 \mathrm{~h}$. G2 arrest was also observed. Overall, we interpret our data as evidence for a significant role of apoptosis in the extensive reorganization of MRC populations that takes place during salinity acclimation, perhaps similar to its well-established role during organismal development.
\end{abstract}

Keywords Apoptosis · Salinity stress ·

Mitochondria-rich cells · Gill epithelial cells ·

Laser scanning cytometry

Communicated by H. V. Carey.

B. D. Kammerer · D. Kültz $(\bowtie)$

Physiological Genomics Group,

Department of Animal Science, University of California,

Davis, One Shields Avenue, Meyer Hall,

Davis, CA 95616, USA

e-mail: dkueltz@ucdavis.edu

\author{
Abbreviations \\ FW Freshwater \\ LSC Laser scanning cytometry \\ MRC Mitochondria-rich cell \\ NKA $\mathrm{Na}^{+} / \mathrm{K}^{+}$ATPase \\ PMT Photomultiplier tube \\ PLL Poly-L-lysine \\ PBA PBS containing 1\% bovine serum albumin \\ PBS Phosphate buffered saline \\ PI Propidium iodide \\ TUNEL Deoxynucleotidyl transferase-mediated dUTP \\ nick end-labeling \\ SW Seawater \\ UV Ultra violet
}

\section{Introduction}

Euryhaline tilapia (Oreochromis mossambicus) tolerate a wide range of salinity and many other types of environmental stress making them a prominent invasive species (Burger et al. 1992; Canonico et al. 2005; Moyle 2000) and a good model organism for studying mechanisms of osmotic stress adaptation (Fiol et al. 2006; Fiol and Kültz 2005). Their ability to thrive in different environments also makes them a robust aquaculture species (Sardella et al. 2004a). Although tilapia are freshwater (FW) fish, they can be cultured efficiently in seawater (SW) and hypersaline water, which is greatly advantageous in light of the global shortage of FW that represents one of the most severe global challenges of our time (Beuhler 2003). For instance, current projections of global climate change forecast increases in estuarine bay area salinities in US coastal water systems of as much as 9 ppt (Knowles and Cayan 2002). Similar projections are predicted for Southeast Asia and other parts of 
the world. Because such significant salinity increase will have dramatic effects on organisms inhabiting these ecosystems, it is critical to study means by which aquatic organisms, notably fishes, physiologically adapt to salinity stress.

Apoptosis represents a physiological adaptation that selectively kills cells by programmed cell death. This physiological mechanism is important during development, differentiation of tissues and organ systems, and for removing terminally damaged cells (Yamashita et al. 2008; Matey et al. 2008; Kültz 2005). Measurements of apoptosis in teleost gill cells in response to salinity stress are sparse. Apoptosis has been detected previously in tilapia gill cells using electron microscopy, but using this method it is difficult to quantify (Wendelaar Bonga and Van Der Meij 1989). In this study we used a microplate reader-based activity assay for caspase 3/7 and laser scanning cytometry (LSC)-based apoptosis assays to quantify apoptosis in mitochondria-rich cell (MRC) and in other gill epithelial cell types. Caspases 3 and 7 are closely related pro-apoptotic effector caspases that activate DNases responsible for nucleosomal DNA fragmentation (Kültz 2005; Lüthi and Martin 2007; Paulsen et al. 2008). We have quantified apoptotic DNA fragmentation in tilapia MRC and other gill cells by LSC using deoxynucleotidyl transferase-mediated dUTP nick endlabeling (TUNEL) assay. The goal of this study was to assess the degree and time-course of apoptosis in MRC and other gill cells to learn whether and how this process contributes to the extensive reorganization of gill epithelium in euryhaline fish exposed to salinity stress.

\section{Methods}

Animals

Tilapia (O. mossambicus) grown from FW laboratory stock, were maintained at the UC Davis Center for Aquatic Biology and Aquaculture at $23-26^{\circ} \mathrm{C}$. Sixty-four fish measuring $9.3 \pm 0.15 \mathrm{~cm}(10.44 \pm 0.4 \mathrm{~g})$ were used for LSC analysis and 12 fish measuring $17.4 \pm 0.5(90.98 \pm 7.0 \mathrm{~g})$ were used for Caspase activity microplate reader assays. They were transferred to recirculating, 38 or 751 glass aquaria filled with FW and fitted with air-stones and maintained at $24-27^{\circ} \mathrm{C}$. They were fed commercial trout pellets up to 2 days before sampling. After 2-3 days pre-acclimation to glass aquaria, tilapia were exposed to $25 \mathrm{~g} / \mathrm{l}$ ( $25 \mathrm{ppt}$ ) diluted SW by first draining tanks to $\sim 1 / 3 \mathrm{FW}$ and refilling to the appropriate salinity by adding warmed SW, collected from the UC Davis Bodega Bay Marine Laboratory. Fish were then allowed to acclimate and sampled at $0,3,6,9,12,24,72$, and $120 \mathrm{~h}$. Temperature was held at $24-27^{\circ} \mathrm{C}$ during all exposures and water was filtered to prevent ammonia accumulation. Salinity was monitored using a light refractometer.
Laser scanning cytometry analysis of caspase 3/7 activity

Fish were sacrificed by overdose with MS222 and rapid spinal transection, followed by gill perfusion with ice-cold $\mathrm{Ca}^{2+}{ }_{-}, \mathrm{Mg}^{2+}$-free phosphate buffered saline (PBS) (Gibco, Invitrogen). Gill epithelial cells were scraped from the filaments, mechanically disassociated, counted, resuspended, and centrifuged onto poly-L-lysine (PLL)-coated coverslips, as described previously (Kammerer et al. 2008). Immediately following adherence of cells, cell-coated coverslips were incubated for $30 \mathrm{~min}$ in a $37^{\circ} \mathrm{C}$ bath with carboxyfluorescein-labeled caspase 3/7 inhibitor (FAM-DEVD-FMK), which binds to active caspase 3/7 (Immunochemistry Technologies, LLC, parts \#93/4). This inhibitor was diluted from $150 \times$ frozen super-stock (reconstituted in DMSO) to $30 \times$ (as per manufacturer's instructions) and again by 1:50 for optimal staining. Following incubation, cells were rinsed thrice: two times in PBS containing 1\% bovine serum albumin (PBA) and once in PBS, each for 5 min. Cells were then fixed in $1 \%$ methanol-free formaldehyde at $\mathrm{pH} 7.5$ (diluted from 10\% stock solution-PolySciences, Inc. \# 04018with PBS). Coverslips were then rinsed once with PBS, and stored overnight in $70 \%$ ethanol $(1 \mathrm{ml})$ at $-20^{\circ} \mathrm{C}$.

Following overnight storage in $70 \%$ ethanol, cell coverslips were rinsed briefly by dipping in PBS three times, incubated in PBA for 30 min., and then blocked in 1\% goat IgG in PBA for $30 \mathrm{~min}$. Coverslips were then incubated with primary $\mathrm{Na}^{+} / \mathrm{K}^{+}$ATPase (NKA) antibody against the avian $\alpha$-subunit developed by Douglas M. Fambrough. This antibody was obtained from the Developmental Studies Hybridoma Bank instituted under the auspices of the National Institute for Child Health and Human Development (NICHD) and maintained by the University of Iowa, Department of Biological Sciences, Iowa City, IA 52242, USA. NKA antibody was diluted in PBA (1\%) 100-fold and coverslips incubated with this solution for $1 \mathrm{~h}$ at room temperature. Following primary NKA antibody incubation, cellcoated coverslips were then rinsed three times for $5 \mathrm{~min}$ in PBS $(0.5 \mathrm{ml})$ in 12-well plates. Pacific-Blue labeled secondary antibody (Invitrogen P-10993) was then diluted to 1:100 in PBA, 1/100th (v/v) of $100 \mu \mathrm{g} / \mathrm{ml}$ thawed RNase solution added (Sigma R-5000), and coverslips incubated in this solution for $30 \mathrm{~min}$. Coverslips were then rinsed three times in PBS for $5 \mathrm{~min}$ before incubation in propidium iodide (PI) to stain DNA. After DNA staining, PI staining solution was removed and coverslips used immediately for LSC analysis.

Trivariate LSC analysis (Compucyte) was performed using an argon laser (488 $\mathrm{nm}$ excitation) for FAM-DEVDFMK (FLICA), and PI, and a ultra violet (UV)-blue laser (400 nm excitation) for Pacific-blue. Cells were detected based on nuclear PI staining and fluorescence recorded in each cell using blue (NKA), green (FLICA), and red (PI) emission photomultiplier tubes (PMTs) and Wincyte 
software (v. 3.6, Compucyte). For each scan, an area of identical size $\left(5 \mathrm{~mm}^{2}\right)$ was scanned using a $20 \times$ fluorescence objective (Olympus). Cell micrographs, galleries, and fluorescence data were recorded using Wincyte software. Cell cycle analysis was performed based on PI fluorescence as previously described (Kammerer et al. 2008).

Microplate-based caspase 3/7 activity assay

Gill epithelia taken from fish exposed to treatment salinities ( 0 or $25 \mathrm{~g} / \mathrm{l}$ ) for $72 \mathrm{~h}$ were homogenized in $0.75 \mathrm{ml}$ buffer (10 mM Tris-HCl pH 7.5, $100 \mathrm{mM} \mathrm{NaCl}, 0.1 \mathrm{mM}$ EDTA, $0.2 \%$ Triton-X), $\mathrm{pH} 7.5$, per $0.25 \mathrm{~g}$ snap-frozen gill tissue in glass homogenizers, on ice. Supernatants were collected after centrifugation at $13,000 \mathrm{~g}$ and $4^{\circ} \mathrm{C}$ for $5 \mathrm{~min}$ and diluted 1,000-fold in homogenization buffer. Caspase 3/7 activity was determined using the Caspase-Glo 3/7 Assay (Promega) using $50 \mu \mathrm{l}$ sample per $50 \mu \mathrm{l}$ of reagent (1:1) with luminescence read after $45 \mathrm{~min}$ incubation at $25^{\circ} \mathrm{C}$ with a Spectrafluor Plus luminescence microplate reader (Tecan). Caspase 3/7 activity was normalized to total protein per sample, which was determined by bicinchoninic acid protein assay (Pierce).

Laser scanning cytometry analysis of apoptotic DNA fragmentation, NKA abundance, and MRC size

To test the effect of salinity on apoptosis measured by TUNEL assay, cells were fixed immediately after attachment on coverslips and stored overnight as described above. Coverslips were rinsed once with wash buffer (Phoenix Flow Systems, \#ABWB13) for $5 \mathrm{~min}$ before incubation with APO-BrdU DNA-labeling solution containing $2 \times$ concentrations recommended as per manufacturer's instructions [20 $\mu 1$ reaction buffer (Phoenix Flow Systems, \#ABRXB14), $1.5 \mu \mathrm{l}$ TdT enzyme (Phoenix Flow Systems, \#ABTD15), and $16 \mu \mathrm{l} \mathrm{Br-dUTP} \mathrm{(Phoenix} \mathrm{Flow}$ Systems, \#ABBU16)] to $0.5 \mathrm{ml}$ total volume. TUNEL incubation was performed in a $37^{\circ} \mathrm{C}$ water bath. Coverslips were then rinsed once with rinse buffer (Phoenix Flow Systems, \#ABRB17) and again with PBS for $5 \mathrm{~min}$. before NKA primary and secondary antibody incubations (1:100). Following NKA labeling, cells were rinsed two times in PBS then once in rinse buffer (Phoenix Flow Systems, \#ABRB17) for 5 min before anti-BrdU antibody incubation using mouse monoclonal Alexa488-labeled (Invitrogen, Molecular Probes \#A21303) secondary antibody (1:200) in rinse buffer for $30 \mathrm{~min}$. Cell-coated coverslips were then rinsed once in PBS for $5 \mathrm{~min}$. before incubation in PI solution (1:500) for $5 \mathrm{~min}$. After DNA staining, PI staining solution was removed and replaced with PBS. Coverslips were stored in PBS at $4{ }^{\circ} \mathrm{C}$ in parafilm-sealed, 12-well plates and kept dark until analysis by LSC. They were analyzed by LSC the following day for TUNEL assay, NKA Abundance, and MRC size. Prior to LSC analysis, cellcoated coverslips were first mounted in 5-10 $\mu \mathrm{l}$ PBS and secured to microscope slides, as described previously (Kammerer et al. 2008).

Trivariate LSC analysis was performed using an argon laser (488 nm excitation) of the laser scanning cytometer (Compucyte) for Alexa488 (TUNEL), PI, and a UV-blue laser (400 nm excitation) for Pacific-blue (NKA), while fluorescence was recorded using blue, green, and red emission PMTs of the LSC. Cells were detected based on PI (red) fluorescence using Wincyte software (v. 3.6, Compucyte) during the first scan, and based on NKA (blue) fluorescence during a second scan that was done to quantify NKA fluorescence per MRC and MRC size. For each scan, an area of identical size $\left(5 \mathrm{~mm}^{2}\right)$ was scanned using a $20 \times$ fluorescence objective. Cell micrographs and galleries were recorded using Wincyte software.

\section{Statistics}

One-way ANOVA was used to assess the effects of time of salinity exposure on apoptosis in tilapia gill cells followed by post hoc Dunnett test after transformation by arcsine square-root (for proportions). Effects of time of salinity exposure on MRC size and NKA abundance per MRC were also analyzed using ANOVA, followed by a Tukey HSD post hoc test. Two-way ANOVA was used to examine combined effects of time of salinity exposure and cell type, followed by post hoc Tukey HSD test on values also transformed by arcsine square-root for proportions for cell cycle analysis. A paired $t$-test was used to analyze the effects of salinity treatment on caspase 3/7 activity in tilapia gill tissue. All statistics were performed using Sigmastat software (v3.5), while graphs were made using Sigmaplot (9.0). Significance was set at $P<0.05$ for all tests and values represent the average of six replicates $(n=6)$; data are presented as the mean \pm standard error of the mean.

\section{Results}

The effect of acute salinity increase on the time-course of caspase 3/7 activity (executioner enzymes of apoptosis) was determined in gill cells bound to coverslips within a representative scan area of $5 \mathrm{~mm}^{2}$ using LSC. A green fluorescent inhibitor that binds to the active site of caspase $3 / 7$ was used (FLICA). Gill cell preparations were also labeled with antibodies against NKA (blue stain) and PI for DNA (red stain) to distinguish caspase activity in MRC from that in other gill cells. Acute SW exposure resulted in a rapid, significant increase in active caspase $3 / 7$ at $6 \mathrm{~h}$ that was sustained through 3 and 5 days, but not significant at 12 and 
Fig. 1 Tilapia increase levels of caspase 3/7-labeled MRC in $\mathrm{SW}$. a FW tilapia gill cells co-labeled with 1 NKA and 2 Pacific-blue antibodies (blue), caspase 3/7 FAM-DEVD-FMK FLICA stain (green), and PI (red). b SW (5 days) tilapia gill cells also triple-stained and at $\times 20$ magnification. $\mathbf{c}$ Proportion of MRC ( $t o p$ ) increase following SW exposure at 6,72 , and $120 \mathrm{~h}$. Non-MRC (bottom) exposed to SW do not change the amount of caspase 3/7-labeled cells. Significance indicated by astericks between mean values $(n=6)$, relative to $\mathrm{FW}(0 \mathrm{~h})$ per cell type

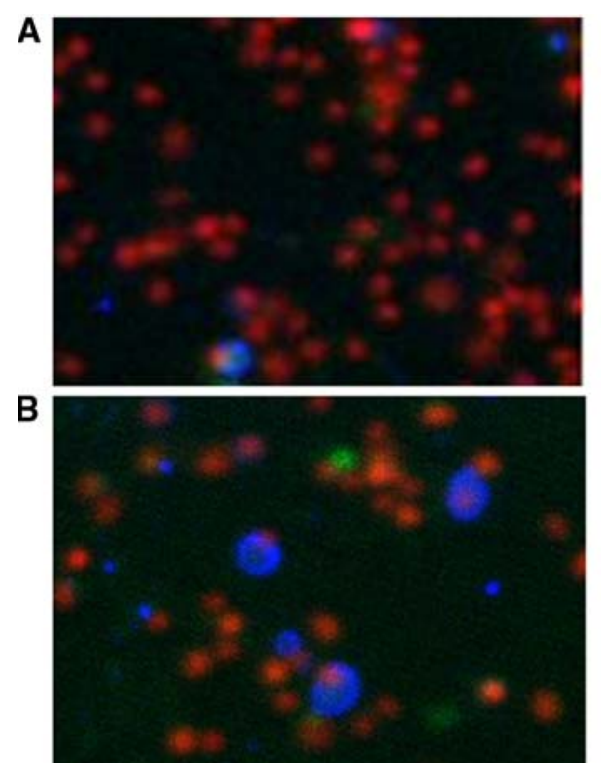

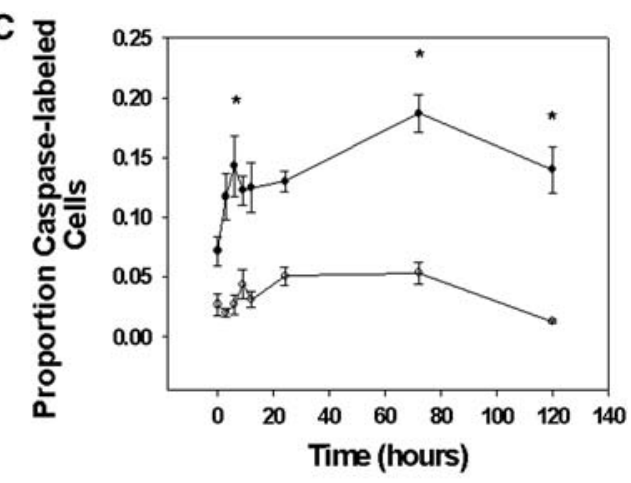

$\rightarrow$ MRC
$24 \mathrm{~h}$ (Fig. 1). Based on this time-course, it is possible that caspase 3/7 activity shows a biphasic increase in response to salinity stress. However, because caspase $3 / 7$ activity is still elevated at 9,12 , and $24 \mathrm{~h}$ it is more likely that the activation of caspase 3/7 is sustained by the MRC over a period of 5 days. Branchial caspase 3/7 activation with salinity exposure of tilapia was confirmed using an alternative method based on luminometry using a microplate reader. Using this assay we observed a 1.6-fold significant increase in caspase 3/7 activity 3 days after SW exposure $(16.61 \pm 1.54)$ compared to controls $(10.39 \pm 2.40)$ (Fig. 2). The magnitude of this increase is slightly lower than the 2.6-fold increase measured in MRC $(0.187 \pm 0.016)$, compared to controls $(0.07 \pm 0.012)$, using LSC. The reason for this difference is the lack of a significant increase of caspase 3/7 activity in gill epithelial cells other than MRC (Fig. 1). Unlike with the LSC-based assay it is not possible to distinguish MRC and other cell types in the microplate-based caspase 3/7 activity assay and, therefore, the activity

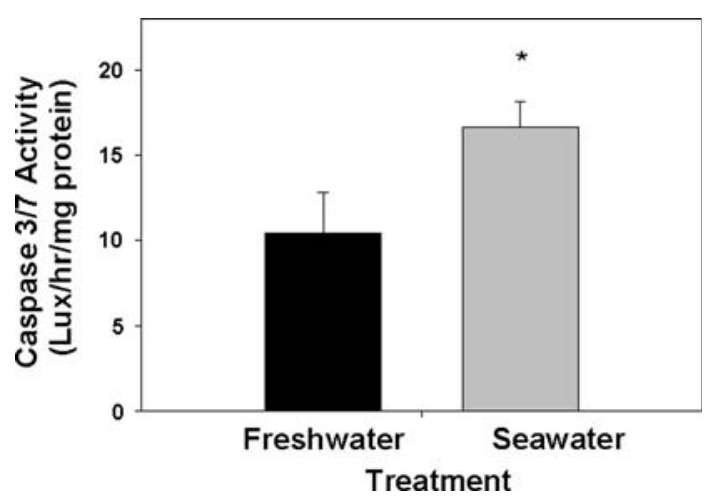

Fig. 2 Tilapia gill caspase 3/7 activity increases at $72 \mathrm{~h}$. Astericks indicate significance between mean values $(n=6)$, relative to FW measured with this assay represents the average activity in all gill cell types.

To confirm the time-course and cell type specificity of apoptosis, we analyzed another hallmark of apoptosis in MRC compared to other gill cell types using LSC. TUNEL assay measures the degree of apoptotic DNA fragmentation by incorporation of a fluorescently labeled nucleotide at the free end of DNA (dUTP-Alexa488). Thus, the amount of fluorescence is proportional to the number of free DNA ends (=degree of DNA fragmentation). Using TUNEL assay we observed essentially identical kinetics of apoptosis in MRC of tilapia exposed to salinity stress as for caspase 3/7 activity. Acute SW exposure resulted in a rapid, significant increase of DNA fragmentation at $6 \mathrm{~h}$ that was sustained at 3 and 5 days, but not significant although quite pronounced at 12 and $24 \mathrm{~h}$ (Fig. 3). In contrast, no significant increase of DNA fragmentation was seen in cell types other than MRC (Fig. 3).

To investigate whether the kinetics of MRC apoptosis correlates with cell cycle changes during salinity acclimation, we determined the proportion of MRC in G1 and G2 phases of the cell cycle based on the intensity of PI staining, where cells in G2 phase were distinguished from those in G1 by having twice the amount of DNA in their nuclei (Kammerer et al. 2008). The proportion of MRC in G2 phase increased significantly (peak 1.4-fold at 3 days) over a period of 5 days in parallel to the observed increase in MRC apoptosis, while MRC in G1 phase of the cell cycle decreased significantly (maximum 1.58 -fold at 3 days) in number (Fig. 4a). The correlation between cells in G1 and G2 phase of the cell cycle was very good indicating that there was a shift of MRC from G1 to G2 phase during salinity acclimation (Fig. 4c). Virtually identical results were obtained for cell types other than MRC. Their G2 proportion 


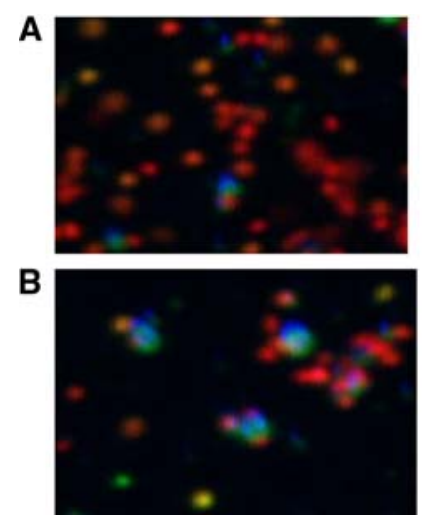

Fig. 3 Tilapia increase levels of TUNEL-labeled MRC in SW. a FW tilapia gill cells labeled with NKA antibodies (blue), TUNEL assay (green), and PI stain (red). b SW tilapia gill cells at $72 \mathrm{~h}$, also triplestained and at $\times 20$ magnification. More TUNEL-positive MRC appear following SW exposure than non-MRC in relation to FW (a). c Propor-

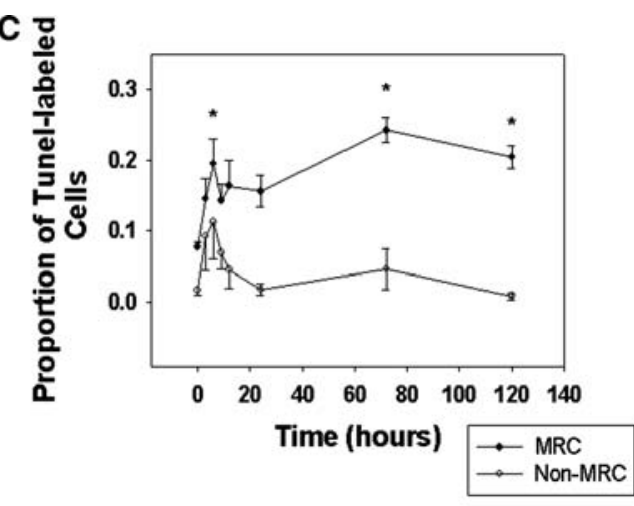

tion of MRC (top) significantly increase levels of cells identified by TUNEL assay (green) at 6,72, and $120 \mathrm{~h}$, while non-MRC (bottom) do not. Significance indicated by astericks between mean values $(n=6)$, relative to FW $(0 \mathrm{~h})$ per cell type
Fig. 4 Shift in the proportion of cells per cell cycle phase in MRC and non-MRC. Tilapia gill cells decrease proportion of cells in G1 phase of the cell cycle, while increasing proportion in $\mathrm{G} 2$ at $72 \mathrm{~h}$ (3 days) in a MRC and $\mathbf{b}$ Non-MRC. Letters indicate significance between mean values $(n=6)$, relative to $\mathrm{FW}$ $(0 \mathrm{~h})$. The correlation of cells in G1 phase of the cell cycle, relative to $\mathrm{G} 2$ phase is represented in c MRC $y=-0.76 x+0.58$ $R^{2}=0.6524$ and $\mathbf{d}$ Non-MRC $y=-0.9 x+0.73 ; R^{2}=0.8596$
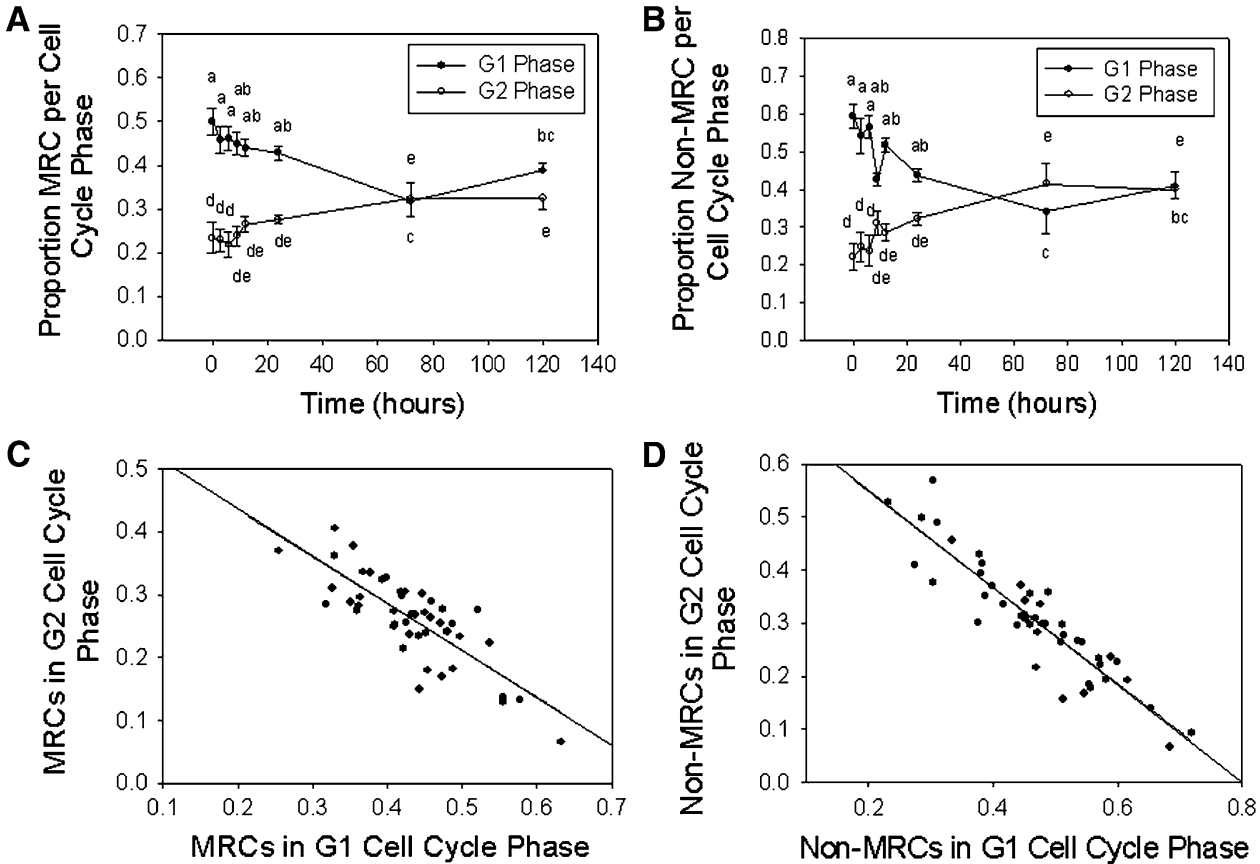

increased significantly (peak 1.88-fold at 3 days), while their G1 proportion decreased significantly (maximum 1.84 -fold at 3 days). The two phases were also closely correlated (Fig. 4b, d).

We were interested in comparing the time-course of MRC apoptosis to the kinetics of NKA abundance in MRC and MRC size to see how these physiological parameters correlate. Significant increases were observed as early as 1 day after initial salinity exposure for NKA abundance per MRC and 3 days after initial salinity exposure for MRC size (Fig. 5). The onset of significant changes in NKA abundance per MRC and MRC size is clearly later than the onset of apoptosis suggesting that apoptosis of a subpopulation of FW MRC and associated redifferentiation of gill epithelium may contribute to adaptive changes of branchial physiology during SW acclimation.

\section{Discussion}

We have shown that a prolonged increase in MRC apoptosis occurs in response to salinity stress in tilapia. Apoptosis starts $6 \mathrm{~h}$ after the initial salinity exposure and lasts for at least 5 days. Two hallmarks of apoptosis, caspase 3/7 activation and DNA fragmentation, have previously been shown to be activated in cultured mammalian kidney cells (Mak and Kültz 2004; Michea et al. 2000). We now show 
Fig. 5 Mitochondria-rich cell increase UV-blue intensity (NKA stain) per cell and size in SW. a A rare, apoptotic FW MRC is less blue and smaller in size than b SW-exposed MRC at 3 days, which also appears more blue. c MRC UV-blue intensity per cell increases by $24-72 \mathrm{~h}$ and through 5 days. $\mathbf{d}$ MRC size increases at $72 \mathrm{~h}$ (3 days) and through 5 days. Letters indicate significance between mean values $(n=6)$, relative to FW $(0 \mathrm{~h})$
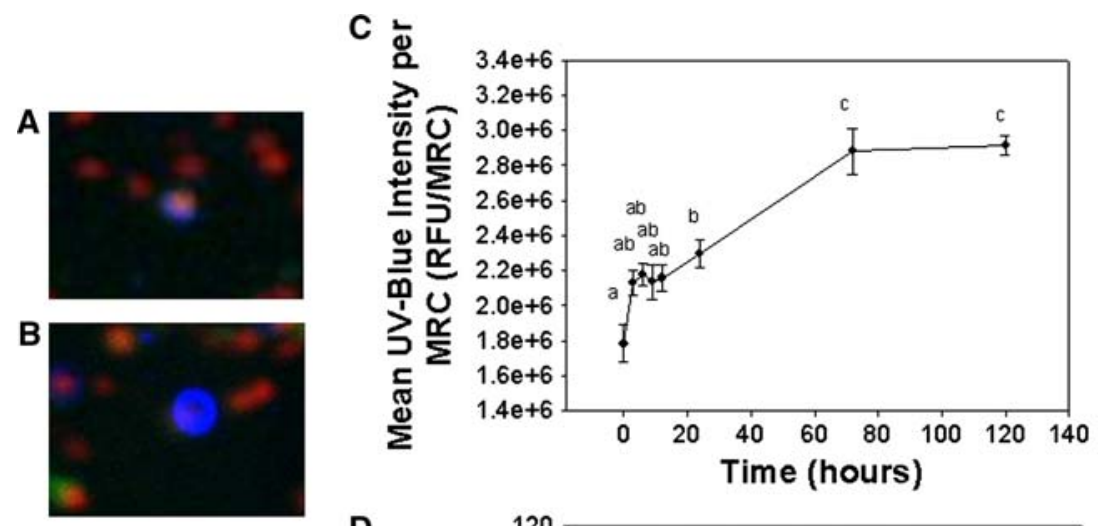

D

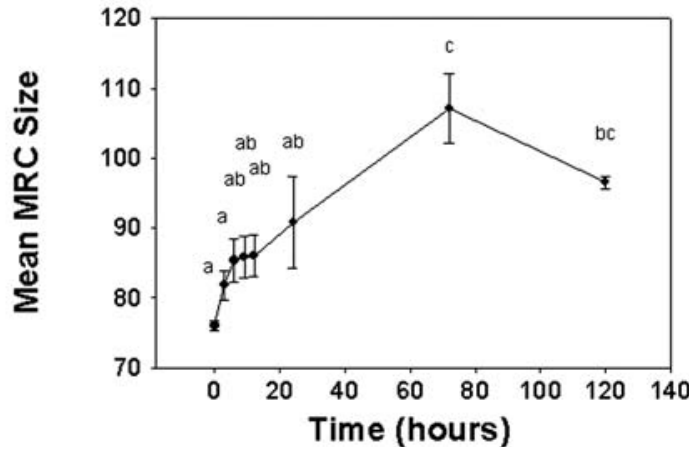

that these parameters also increase in MRC after salinity exposure of tilapia. Caspase 3/7 activity and DNA fragmentation increase in response to salinity stress in MRC, but not in other gill epithelial cells. Both hallmarks of apoptosis are downstream of the convergence point for extrinsic and intrinsic apoptotic signaling cascades (Lüthi and Martin 2007). Therefore, we are currently not able to discern whether salinity-induced apoptosis of MRC is mediated via the extrinsic or the intrinsic pathway. Of interest, although not significant, there was an increasing trend in DNA fragmentation in non-MRC that peaks at $6 \mathrm{~h}$ and could be due to direct DNA damage shortly after the initial salinity exposure (Kültz and Chakravarty 2001). Nevertheless, the sustained 5-day increase in apoptotic DNA fragmentation observed in MRC was not seen in other gill cell types, indicating that MRC apoptosis is likely not a result of non-specific damage inflicted during hyperosmotic salinity stress, but rather a specific process that supports MRC differentiation during SW acclimation.

Our data show that MRC experienced apoptosis more readily than other cell types in response to salinity stress. This observation suggests that reorganization of branchial MRC population due to accelerated turnover of this cell type contributes significantly to salinity acclimation. It also suggests that a significant portion of FW MRC is replaced by new SW MRC during salinity stress rather than being remodeled or redifferentiated into SW MRC. Because it has been observed previously in tilapia yolk-sac epithelium that MRC also redifferentiate from the $\mathrm{FW}$ into the
SW phenotype rather than being replaced (Hiroi et al. 2005) it may be possible that both types of regulation apply [(a) MRC replacement due to apoptosis and de-novo differentiation, and (b) redifferentiation of existing MRC from FW to SW phenotype]. The prolonged time-course of apoptosis observed in this study corresponds well with the acute acclimation period, during which the gill epithelium is reorganized, branchial ion transport is altered, and MRC are greatly modified (Foskett et al. 1981; Hwang et al. 1989). Our data also correlate with a rapid transient increase in mitotic MRC that reaches its maximum at $8 \mathrm{~h}$ following salinity exposure in tilapia (Kammerer et al. 2008), as well as increased MRC turnover measured in other teleost species (Chretien and Pisam 1986).

However, because changes in the overall distribution of MRC in the two most prominent cell cycle stages (G1 and G2) are similar to those of other cell types, our results indicate that cells accumulating in $\mathrm{G} 2$ phase may primarily be a consequence of $\mathrm{G} 2 / \mathrm{M}$ cell cycle arrest to allow time for acclimation and that such cell cycle arrest is activated in all gill cell types. G2/M arrest is a common cell cycle checkpoint that is activated during osmotic stress in yeast, mammalian cells, and tilapia gill cells (Kammerer et al. 2008; Kültz et al. 1998; Shiozaki and Russell 1996).

In contrast to the ubiquitous effect of salinity on G2 arrest of gill epithelial cells, apoptosis increases significantly only in MRC but not in other cell types, at least during the moderate salinity stress used in this study (acute exposure from FW to $25 \mathrm{ppt} \mathrm{SW}$ ). Thus, our results suggest 
that apoptosis plays a more active role in adaptive redifferentiation of gill epithelium rather than just being a process for removal of non-specifically damaged cells. If the latter were true we would expect to observe a comparable degree of apoptosis in MRC and other cell types, which is clearly not the case. The prolonged time-course of apoptosis in MRC is supported by an earlier electron microscopy study that showed that tilapia MRC apoptosis is significantly increased several days after transfer from FW to SW (Wendelaar Bonga and Van Der Meij 1989). In addition, our results agree with a previous study that predicted that tilapia increase apoptosis by two- to threefold several days after acute salinity stress for every $20-30 \mathrm{~g} / \mathrm{l}$ increase in salinity (Sardella et al. 2004b).

In this study we used NKA antibody as a marker for MRC. At the same time, this antibody enabled us to quantify NKA abundance in individual MRC and to determine MRC size. While NKA antibodies have previously been used as a MRC marker (Lima and Kültz 2004; Sardella et al. 2008) and MRC size has often been measured after live DAPSMI/DASPEI staining (Foskett et al. 1981; Kültz et al. 1992; Van Der Heijden et al. 1997), the fixation of whole cells on PLL-coated coverslips allowed us to combine these two approaches and utilize NKA antibodies for determination of MRC size in fixed, dissociated cell populations. This method is advantageous over live cell stains such as DASPMI when co-labeling with dyes that require fixed cells is desired (for instance TUNEL labeling) and also to measure NKA abundance per MRC. Our data show that significant changes in NKA abundance per MRC occur significantly later than the onset of apoptosis, suggesting that MRC apoptosis may contribute to the reorganization of MRC populations during salinity stress. This argument is also supported by a relatively slow increase in NKA activity in gills of tilapia following salinity transfer (Dange 1985; Hwang et al. 1989). Likewise, significant changes in MRC size only occurred several days after the onset of MRC apoptosis, which is consistent with previous studies based on MRC DASPMI staining and electron microscopy (Cioni et al. 1991; Uchida et al. 2000; Van Der Heijden et al. 1997).

Taken together, we interpret the results of our study as indicative of a significant role of apoptosis in the reorganization of gill epithelium, in particular in the physiological adjustments of MRC populations when tilapia are exposed to hyperosmotic salinity stress.

Acknowledgments This project was supported by grant \#IOB0542755 from the National Science Foundation (NSF) and comply with IACUC standards (Protocol \#15013) of University of California Davis, USA. We would like to especially thank Dr Brian Sardella for his insight, as well as Marie Ihara, Cesar Morales-Pacheco, Amanda Schwabe, and Enio Sanmarti for help with fish sampling and care. We would also like to thank Dr Thomas Famula and Jerome Braun for advice with statistical analysis as well as the UC Davis Center for Aquatic Biology and Aquaculture for their help with maintenance of fish prior to experiments.

Open Access This article is distributed under the terms of the Creative Commons Attribution Noncommercial License which permits any noncommercial use, distribution, and reproduction in any medium, provided the original author(s) and source are credited.

\section{References}

Beuhler M (2003) Potential impacts of global warming on water resources in Southern California. Water Sci Technol 47:165-168

Burger J, Cooper K, Gochfeld DJ, Saliva JE, Safina C, Lipsky D, Gochfeld M (1992) Dominance of Tilapia mossambica, an introduced fish species, in three Puerto Rican estuaries. Estuaries 15:239-245

Canonico GC, Arthington A, McCrary JK, Thieme ML (2005) The effects of introduced tilapias on native biodiversity. Aquat Conserv Mar Freshw Ecosyst 15:463-483

Chretien M, Pisam M (1986) Cell renewal and differentiation in the gill epithelium of fresh-water-adapted or salt-water-adapted euryhaline fish as revealed by [H-3] thymidine autoradiography. Biol Cell 56:137-150

Cioni C, Merich DD, Cataldi E, Cataudella S (1991) Fine structure of chloride cells in FW and SW-adapted Oreochromis niloticus (Linnaeus) and Oreochromis mossambicus (Peters). J Fish Biol 29:197-209

Dange AD (1985) Branchial $\mathrm{Na}^{+}-\mathrm{K}^{+}$-ATPase activity during osmotic adjustments in two freshwater euryhaline teleosts, tilapia (Sarotherodon mossambicus) and orange chromid (Etroplus maculatus). Mar Biol 87:101-107

Fiol DF, Kültz D (2005) Rapid hyperosmotic coinduction of two tilapia (Oreochromis mossambicus) transcription factors in gill cells. Proc Natl Acad Sci USA 102:927-932

Fiol DF, Chan SY, Kültz D (2006) Identification and pathway analysis of immediate hyperosmotic stress responsive molecular mechanisms in tilapia (Oreochromis mossambicus) gill. Comp Biochem Physiol Part D 1:344-356

Foskett JK, Logsdon CD, Turner T, Machen TE, Bern HA (1981) Differentiation of the chloride extrusion mechanism during SW adaptation of a teleost fish, the cichlid Sarotherodon mossambicus. J Exp Biol 93:209-224

Hiroi J, Miyazaki H, Katoh F, Ohtani-Kaneko R, Kaneko T (2005) Chloride turnover and ion-transporting activities of yolk-sac preparations (yolk balls) separated from Mozambique tilapia embryos and incubated in freshwater and seawater. J Exp Biol 208:3851-3858

Hwang P, Sun CM, Wu SM (1989) Changes of plasma osmolarity, chloride concentration and gill Na-K ATPase activity in tilapi (O. mossambicus) during seawater acclimation. Mar Biol 100:295-299

Kammerer B, Sardella BA, Kültz D (2008) Salinity stress results in rapid changes in cell cycle of tilapia (Oreochromis mossambicus) gill epithelial cells. J Exp Zool 309A:1-11

Knowles N, Cayan DR (2002) Potential effects of global warming on the Sacramento/San Joaquin watershed and the San Francisco estuary. Geophys Res Lett 29(18):1891

Kültz D (2005) Molecular and evolutionary basis of the cellular stress response. Annu Rev Physiol 67:225-257

Kültz D, Chakravarty D (2001) Maintenance of genomic integrity in mammalian kidney cells exposed to hyperosmotic stress. Comp Biochem Physiol Part A 130:421-428 
Kültz D, Bastrop R, Jurss K, Siebers D (1992) Mitochondria-rich (MR) cells and the activities of the $\mathrm{Na}^{+} / \mathrm{K}^{+}$-ATPase and carbonic anhydrase in the gill and opercular epithelium of Oreochromis mossambicus adapted to various salinities. Comp Biochem Physiol 102B:293-301

Kültz D, Madhany S, Burg MB (1998) Hyperosmolality causes growth arrest of murine kidney cells-induction of GADD45 and GADD153 by osmosensing via stress-activated protein kinase. J Biol Chem 273:13645-13651

Lima RN, Kültz D (2004) Laser scanning cytometry and tissue microarray analysis of salinity effects on killifish chloride cells. J Exp Biol 207:1729-1739

Lüthi AU, Martin SJ (2007) The CASBAH: a searchable database of caspase substrates. Cell Death Differ 14:641-650

Mak S, Kültz D (2004) Gadd45 proteins induce $\mathrm{G}_{2} / \mathrm{M}$ arrest and modulate apoptosis in kidney cells exposed to hyperosmotic stress. J Biol Chem 279:39075-39084

Matey V, Richards JG, Wang Y, Wood CM, Rogers J, Davies R, Murray BW, Chen XQ, Du J, Brauner CJ (2008) The effect of hypoxia on gill morphology and ionoregulatory status in the Lake Qinghai scaleless carp, Gymnocypris przewalskii. J Exp Biol 211:1063-1074

Michea L, Ferguson DR, Peters DM, Andrews PM, Kirby MR, Burg MB (2000) Cell cycle delay and apoptosis are induced by high salt and urea in renal medullary cells. Am J Physiol Renal Physiol 278:F209-F218

Moyle PB (2000) A list of freshwater, anadromous, and euryhaline fishes of California. Calif Fish Game 86:244-258

Paulsen M, Ussat S, Jakob M, Scherer G, Lepenies I, Schütze S, Kabelitz D, Adam-Klages S (2008) Interaction with XIAP prevents full caspase-3/-7 activation in proliferating human $T$ lymphocytes. Eur J Immunol 38:1-9

Sardella BA, Cooper JC, Gonzalez RJ, Brauner CJ (2004a) The effect of temperature on juvenile Mozambique tilapia hybrids
(Oreochromis mossambicus $\times$ O. urolepis hornorum) exposed to full-strength and hypersaline seawater. Comp Biochem Physiol Part A 137:621-629

Sardella BA, Matey V, Cooper JC, Gonzalez RJ, Brauner CJ (2004b) Physiological, biochemical and morphological indicatorys of osmoregulatory stress in 'California' Mozambique tilapia (Orechromis mossambicus $\times$ O. urolepis hornorum) exposed to hypersaline water. J Exp Biol 207:1399-1413

Sardella BA, Kültz D, Cech JJJ, Brauner CJ (2008) Salinity-dependent changes in $\mathrm{Na}+/ \mathrm{K}+-$ ATPase content of mitochondria-rich cells contribute to differences in thermal tolerance of Mozambique tilapia. J Comp Physiol B 178:249-256

Shiozaki K, Russell P (1996) Conjugation, meiosis, and the osmotic stress response are regulated by Spc1 kinase through Atf1 transcription factor in fission yeast. Genes Dev 10:2276-2288

Uchida K, Kaneko T, Miyazaki H, Hasegawa S, Hirano T (2000) Excellent salinity tolerance of Mozambique tilapia (Oreochromis mossambicus): elevated chloride cell activitiy in the branchial and opercular epithelia of the fish adapted to concentrated seawater. Zoolog Sci 17:149-160

Van Der Heijden AJH, Verbost PM, Eygensteyn J, Li J, Wendelaar Bonga SE, Flik G (1997) Mitochondrial-rich cells in gills of the tilapia (Oreochromis mossambicus) adapted to freshwater or seawater: quantification by confocal laser scanning microscopy. J Exp Biol 200:55-64

Wendelaar Bonga SE, Van Der Meij JCA (1989) Degeneration and death, by apoptosis and necrosis, of the pavement and chloride cells in the gills of the teleost Oreochromis mossambicus. Cell Tissue Res 255:235-243

Yamashita M, Mizusawa N, Hojo M, Yabu T (2008) Extensive apoptosis and abnormal morphogenesis in pro-caspase-3 transgenic zebrafish during development. J Exp Biol 2008:1874-1881 